\title{
Seed germination and vigor of passion fruit hybrids
}

\author{
Antônio Gustavo de Luna Souto, João Paulo Gava Cremasco, \\ Mariana Quintas Maitan, Jéssica Laisca Fernanda de Azevedo, \\ Mariana Rodrigues Ribeiro, Carlos Eduardo Magalhães dos Santos
}

Universidade Federal de Viçosa, Viçosa, MG, Brazil

*Corresponding author, e-mail: gusluso@hotmail.com

\begin{abstract}
Most commercial plantations of passion fruit is propagate plants by seed, but germination is irregular, which hinders the growth of seedlings and uniformity, and is connected with the plant genotype. The objective of this study was to evaluate the germination and early growth of passion fruit hybrid seedlings, obtained from different genetic combinations. The hybrids were obtained from the cross between progenies from the breeding program of the Universidade Federal de Viçosa with hybrids of the Empresa Brasileira de Pesquisa Agropecuária and of the Viveiros Flora Brasil. The experimental design was completely randomized with six hybrids, five replicates and fifty seeds per experimental unit. Germination was assessed daily until the 28 days, and at the end of the period it was obtained the mean time germination, emergence speed index, seedling height, the length of shoots and roots, and the individual seedling dry matter (root + shoot)was assessed. Among the passion fruit hybrids evaluated, hybrid HB2 (UFVM0212 × BRS Sol do Cerrado) showed the highest germination and seedling biometric values and might be a genotype with potential for breeding programs for seed quality. The specific combining ability of parents can influence the quality of seeds and the vigor of passion fruit seedlings. A factor must be considered is the correct choice of maternal and paternal parents, since they influence the quality of seeds.
\end{abstract}

Keywords: biometrics, combining ability, emergency, Passiflora edulis

\section{Germinação de sementes e vigor de híbridos de maracujazeiro}

\section{Resumo}

A maioria das plantações comerciais de maracujazeiro é propagada por sementes, mas a germinação é irregular, o que dificulta o crescimento das mudas e sua uniformidade, e está ligado ao genótipo da planta. Objetivou-se no trabalho, avaliar a germinação e o crescimento inicial em plântulas de híbridos de maracujazeiro, obtidos de diferentes combinações genéticas. Os híbridos foram obtidos do cruzamento de progênies do programa de melhoramento da Universidade Federal de Viçosa com híbridos comerciais da Empresa Brasileira de Pesquisa Agropecuária e do Viveiro Flora Brasil. O delineamento experimental utilizado foi o inteiramente casualizado, com seis híbridos, cinco repetições e cinquenta sementes por unidade experimental. A germinação foi avaliada diariamente até 28 dias, e ao final do período foi obtido o tempo médio de germinação, o índice de velocidade de emergência, a altura da planta, o comprimento da parte aérea e da raiz e massa seca individual das plântulas (raiz + parte aérea). Entre os híbridos de maracujazeiro avaliados, o híbrido HB2 (UFVM0212 × BRS Sol do Cerrado) apresentou os maiores valores de germinação e biométricos de mudas e pode ser um genótipo com potencial para programas de melhoramento para qualidade de semente. A capacidade específica entre os pais pode influenciar a qualidade das sementes e o vigor das mudas de maracujazeiro. Um fator que deve ser considerado é a escolha correta dos pais maternos e paterno, uma vez que eles influenciam a qualidade das sementes.

Palavras chave: biometria, capacidade de combinação, emergência, Passiflora edulis 


\section{Introduction}

The passion fruit (Passiflora edulis Sims) is a fruit native to the tropical climate of Brazil, and plays an important role in national fruit production by providing a rapid return on invested capital in crop establishment and a more distributed revenue opportunity throughout the year (Araújo Neto et al., 2009; Meletti, 2011).

Passion fruit juice is important to consumers due to its nutritional value, because it is rich in vitamin A, niacin, riboflavin and ascorbic acid; in addition, the fruit peel is used as a source of proteins for animals and the seeds are used in the oil extraction industry for cosmetics (Tommonaro et al., 2007; Zeraik et al., 2010).

Passion fruit can be sexually propagated by seed or asexually by cuttings, by grafting or tissue culture (Alexandre et al., 2004). In Brazil, sexual propagation by seed is the most used method in commercial plantations, due to the rapidity which plants can be brought to the orchard (Aguiar et al., 2014). However, the time taken for the seeds of passion fruit to germinate can vary from ten days to three months, which hinders seedling growth and uniformity (Lima et al., 2009).

The physiological quality of the seed is influenced by genotype, and reaches a maximum at maturity (Negreiros et al., 2008).Parameters such as seed quality, emergence and seedling vigor are linked to the plant genotype and interact with the environment (Lone et al., 2014; Merganda et al., 2014). According to Campostini \& Glenn (2007), understanding this interaction can contribute to passion fruit breeding programs. Alexandre et al. (2004) and Negreiros et al. (2008) found that the germination and emergence rate in passion fruit are influenced by the genotypes.

The germination of passion fruit is influenced by seed dormancy, which may be related to genetic control, in which some genetic combinations allow different germination behavior. Pádua et al. (2011) reported that low germination of Passiflora can be of genetic origin due to variation between species and cultivars.

Thus, the aim of this study was to evaluate the germination and early growth of passion fruit hybrid seedlings, obtained from different genetic combinations.

\section{Material and Methods}

The treatments consisted of six passion fruit hybrids obtained by controlled pollination between progeny(Table 1) from the breeding program of the Universidade Federal de Viçosa with hybrids of Empresa Brasileira de Pesquisa Agropecuária (EMBRAPA - BRS) and Viveiro Flora Brasil (FB). The experimental design was a completely randomized, with five replicates and 50 seeds per experimental unit.

Table 1. Hybrids of passion fruit and its parents.

\begin{tabular}{lcc}
\hline Hybrids & \multicolumn{2}{c}{ Parents } \\
\cline { 2 - 3 } HB 1 & Female & Male \\
HB 2 & UFVM1812 & UFVM1312 \\
HB 3 & UFVM0212 & BRS Sol do Cerrado \\
HB 4 & UFVM0112 & BRS Sol do Cerrado \\
HB 5 & UFVM1512 & UFVM0712 \\
HB 6 & UFVM1512 & BRS Gigante Amarelo \\
\hline
\end{tabular}

The fruits were harvested when approximately $30 \%$ of the skin was yellow. Extraction of the seeds was carried out by immersion in a solution containing $10 \%$ lime, by rubbing the seeds through a sieve to remove aryl, then washing the seeds in water. The seeds were placed on paper towels at room temperature $( \pm$ $25^{\circ} \mathrm{C}$ ) to remove excess humidity for two days, and following drying, aryl residues still adhering to the seed were removed and the seeds were manually counted, and then stored in a refrigerator at $5^{\circ} \mathrm{C}$ for 30 days.

The seeds were placed in plastic trays containing washed inert sand and distributed in grooves at a depth of $3 \mathrm{~cm}$, been maintained in BOD adjusted to $25 \pm 2^{\circ} \mathrm{C}$ for 28 days. Irrigation was performed daily with distilled water.

Germination evaluation was performed daily until twenty-eight days after sowing, considering seedlings with fully expanded 
cotyledon leaves. Following this 28-day period, seedling height, the length of shoots and roots and the individual seedling dry matter (root+shoot) was evaluated, in addition, to the mean germination time (MGT) and emergence speed index (ESI) of passion fruit hybrids.

The ESI was determined using the formula of Nakagawa (1999). The MGT was calculated

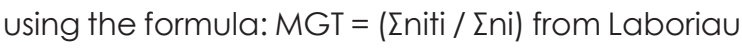
(1983), where $\mathrm{ni}=$ the number of germinated seeds per day, $t i=$ the number of days from the first emergence to final evaluation date and $\mathrm{i}=$ 7 to 28 days, representing the uniformity in days.

The data were submitted to analysis of variance by the $\mathrm{F}$ test and the means were compared by the Scott-Knott test at $5 \%$ probability. Percentage germination data were arcsine-transformed $(x / 100)^{1 / 2}$ and were analysed using SISVAR statistical software (Ferreira, 2011).

\section{Results and Discussion}

The percentage germination and emergence speed index (ESI) differed among the hybrids (Table 2). The hybrid HB2 showed the best performance with values of $84 \%$ and 4.0, respectively for percentage germination and emergence speed index. The hybrid HB6 showed the lowest percentage germination with only $3 \%$ of emerged seeds, and a slower rate of germination (0.010); however, this rate did not differ statistically from theHB1 (0.500) and HB3 $(0.500)$ hybrids. Evaluating progenies of passion fruit, Negreiros et al. (2008) observed rate of seed germination fluctuate 1.5 to $84 \%$ and those that germinated above $50 \%$ were the ones that showed the highest emergence speed index values, similar to results obtained in hybrid HB2.

The seeds germination in general, is the result of selection of the best genotypes (Alexandre et al., 2004; Lone et al., 2014), and most fundamental is the choice of potential parents with a higher germination ability, which is a key agronomic trait for the establishment of plants in the orchard. This is shown by the results found in the hybrid HB2, which might be related to a specific combination of maternal and paternal parents.

The results agree with those of Alexandre et al. (2004), who reported that the percentage germination and the emergence speed index of passion fruit seeds are predominantly influenced by the plant genotype. This was also observed for different species of Passiflora, with the best results for Passiflora edulis (Lima et al., 2006).

The mean germination time did not differ among passion fruit hybrids and was about 12 days (Table 2), which was the same as that reported by Bellé \& Kämpf (1993). According to Negreiros et al. (2008), the mean germination time and its uniformity are extremely important, and this variable can efficiently increase seedling production on a commercial scale.

Table 2.Mean germination percentage, mean germination time and emergence speed indexfor hybrids of passion fruit.

\begin{tabular}{cccc}
\hline Hybrids & Mean germination percentage (\%) & Mean germination time (days) & Emergence speed index \\
HB 1 & $16.50 \mathrm{c}$ & 13.00 & $0.50 \mathrm{c}$ \\
HB 2 & $84.00 \mathrm{a}$ & 11.75 & $4.00 \mathrm{a}$ \\
HB 3 & $17.50 \mathrm{c}$ & 12.00 & $0.50 \mathrm{c}$ \\
HB 4 & $30.50 \mathrm{~b}$ & 11.50 & $1.25 \mathrm{~b}$ \\
HB 5 & $25.00 \mathrm{~b}$ & 13.00 & $1.00 \mathrm{~b}$ \\
HB 6 & $3.00 \mathrm{~d}$ & 11.50 & $0.01 \mathrm{C}$ \\
\hline F-test & $100.342^{* *}$ & $1.127^{\mathrm{ns}}$ & $53.945^{* *}$ \\
\hline CV (\%) & 19.21 & 10.92 & 32.35 \\
\hline Mean & 29.41 & 12.12 & 1.20 \\
\hline Means followed by the same lower-case letter in the column do not differ by the Scott-Knott test $(p<0.05)$, ns = not significant, $\mathrm{CV}=$ coefficient of variation.
\end{tabular}

Among the mean values of biometrics for seedlings of passion fruit hybrids, significant differences $(p<0.05)$ were observed for seedling height, total length and individual dry matter and no statistically significant differences were observed for root length, with average values of

\section{$4.37 \mathrm{~cm}$ (Table 3).}

The HB6 hybrid was the tallest hybrid, reaching $4.75 \mathrm{~cm}$ and did not differ statistically in height from hybrids HB4 and HB5, which both had a mean height of $4.5 \mathrm{~cm}$. Among the hybrids, $\mathrm{HB} 1$ was the least vigorous in height compared 
to other hybrids; with a mean of $3.25 \mathrm{~cm}$.The results of seedling height observed in this study, regardless of hybrids tested, were higher than the variation 1.03 to $2.33 \mathrm{~cm}$ obtained by Lima et al. (2009) in seedlings passion fruit subjected to dormancy breaking treatment.

Table 3. Mean seedling height, root length, total length and individual dry matter for passion fruit hybrids.

\begin{tabular}{ccccc}
\hline Hybrids & Seedling height $(\mathrm{cm})$ & Root length $(\mathrm{cm})$ & Total length $(\mathrm{cm})$ & Individual dry matter $(\mathrm{mg})$ \\
\hline HB 1 & $3.25 \mathrm{c}$ & 4.25 & $7.50 \mathrm{~b}$ & $7.20 \mathrm{~b}$ \\
HB 2 & $4.00 \mathrm{~b}$ & 5.00 & $9.00 \mathrm{a}$ & $95.43 \mathrm{a}$ \\
HB 3 & $4.00 \mathrm{~b}$ & 4.25 & $8.25 \mathrm{a}$ & $45.88 \mathrm{~b}$ \\
HB 4 & $4.50 \mathrm{a}$ & 4.50 & $9.00 \mathrm{a}$ & $9.65 \mathrm{~b}$ \\
HB 5 & $4.50 \mathrm{a}$ & 4.25 & $8.75 \mathrm{a}$ & $8.54 \mathrm{~b}$ \\
HB 6 & $4.75 \mathrm{a}$ & 4.00 & $8.75 \mathrm{a}$ & $0.48 \mathrm{~b}$ \\
\hline F-test & $5.526^{* *}$ & $2.552^{\text {ns }}$ & $5.606^{* *}$ & $4.386^{*}$ \\
\hline CV (\%) & 11.03 & 9.86 & 6.20 & 131.90 \\
\hline Mean & 4.16 & 4.37 & 8.45 & 27.86 \\
\hline Means followed by the same lower-case letter in each column do not differ using the Scott-Knott test $(p<0.05)$, ns = not significant, CV = Coefficient of variation.
\end{tabular}

The highest total seedling length was shown by hybrids HB2 and HB3 $(8.50 \mathrm{~cm})$, and HB5, HB6 $(8.75 \mathrm{~cm})$ and HB4 $(9.00 \mathrm{~cm})$, although the differences between them were not statistically significant. Hybrid HBlshowed the lowest mean values $(7.25 \mathrm{~cm})$ in vigorin total seedling length (Table3). The determination of the mean length of seedlings needed is a variable so that the samples (hybrids) which have larger mean values of full length are more vigorous (Nakagawa, 1999).

The largest individual dry matter accumulation in passion fruit seedlings was found in the hybrid HB2, with values of 95.43 $\mathrm{mg}$, different from the other hybrids. The largest individual dry matter accumulation in passion fruit seedlings was found in the hybrid HB2, with values of $95.43 \mathrm{mg}$, different from the other hybrids, where dry matter varied from 0.78 to $45.88 \mathrm{mg}$, not have to difference between them.Similar results were verified by Alexandre et al. (2004), in describing that there are differences in dry matter accumulation of seedlings of genotypes evaluated passion fruit, and seedling vigor is a factor that must be considered in the breeding.

Because passion fruit is an alogam plant, attention should be paidto the correct choice of the parents and crosses should be selected to maximize the use of favorable genes or exploit heterosis by crossing individuals with good agronomic characteristics and a certain degree of genetic divergence, to generate superior varieties (Negreiros et al., 2008).

\section{Conclusions}

Among the passion fruit hybrids evaluated, hybrid HB2 (UFVM0212 × BRS Sol do Cerrado) showed the highest germination and seedling biometric values and might show genotypic potential for breeding programs for seed quality;

The specific combining ability of parents can influence the quality of seeds and vigorof passion fruit seedlings;

The correct choice of maternal and paternal parents is a factor that must be considered, since they influence the quality of seeds.

\section{References}

Aguiar, R.S., Yamamoto, L.Y., Petri, E.A., Souza, G.R.B., Sbrussi, C.A.G., Oliveira, E.A.P., Assis, A.M., Roberto, S.R., Neves, C.S.V.J. 2014. Extração de mucilagem e substratos no desenvolvimento deplântulas de maracujazeiro-amarelo. Semina: CiênciasAgrárias 35: 605-612.

Alexandre, R.S., Wagner Júnior, A., Negreiros, J.R.S., Parizzotto, A., Bruckner, C.H. 2004. Germinação de sementes de genótipos de maracujazeiro. Pesquisa Agropecuária Brasileira 39: 1239-1245.

Araújo Neto, S.E., Souza, S.R., Saldanha, C.S., Fontinele, J.R.S., Mendes, R., Azevedo, J.M.A., Oliveira, E.B.L. 2009. Produtividade e vigor do maracujazeiro-amarelo plantado em covas e plantio direto sobmanejo orgânico. Ciência Rural 39: 678-683.

Bellé, S., Kämpf, A.N. 1993. Produção de mudas de maracujazeiro-amarelo em substratos à base de turfa. Pesquisa Agropecuária Brasileira28: 385390. 
Campostrini, E., Glenn, D.M.2007. Ecophysiologyofpapaya: a review. Brazilian Journal of Plant Physiology 19: 413-424.

Ferreira, D.F. 2011 . Sisvar: a computer statistical analysis system. Ciência e Agrotecnologia 35: 1039-1042.

Laboriau, L.G. 1983. A germinação das sementes. Washington: D. C., Secretaria Geral de Organização dos Estados Americanos, USA. $174 p$.

Lima, A.A., Caldas, R.C., Santos, V.S. 2006. Germinação e crescimento de espécies de maracujá. Revista Brasileira de Fruticultura 28: 125-127.

Lima, C.S.M., Betemps, D.L., Tomaz, Z.F.P., Galarça, S.P., Rufato, A. R. 2009. Germinação de sementes e crescimento de maracujá em diferentes concentrações do ácido giberélico, tempos de imersão e condições experimentais. Revista Brasileira de Agrociência 15: 43-48.

Lone, A.B., Colombo, R.C., Favetta, V., Takahashi, L.S.A., Faria, R. T. 2014. Temperatura na germinação de sementes de genótipos de pitaya. Semina: Ciências Agrárias 35: 2251-2258.

Melleti, L.M.M. 2011. Avanços na cultura do maracujá no Brasil. Revista Brasileira de Fruticultura 33: 83-91.

Mengarda, L.H.G., Lopes, J.C., Buffon, R.B. 2014. Emergência e vigor de mudas de genótipos de mamoeiro em função da irradiância. Pesquisa Agropecuária Tropical 44: 325-333.

Nakagawa, J. 1999. Testes de vigor baseados no crescimento de plântulas. In: Krzyzanowski,F.C. Vieira, R.D., França-Neto, J.B. (ed.) Vigor de sementes: conceitos e testes. ABRATES, Londrina, Brasil. p. 2-21.

Negreiros, J.R.S., Alexandre, R.S., Álvares, V.S., Bruckner, C.H., Cruz, C.D. 2008. Divergência genética entre progênies de maracujazeiroamarelo com base na característica das plântulas. Revista Brasileira de Fruticultura 30: 197-201.

Pádua, J.G., Schwingel, L.C., Mundim, R.C., Salomão, A.N., Roverijosé, J.S.C.B. 2011. Germinação de sementes de Passiflora setacea e dormência induzida pelo armazenamento. Revista Brasileira de Sementes 33: 80-085.

Tommonaro, G., Rodriguez, C.S.S., Santillana, M., Immirzi, B. Prisco, R.,Nicolaus, B., Poli, A. 2007. Chemical composition and biotechnological properties of a polysaccharide from the peels and antioxidative content from the pulp of Passifloraliguralisfruits. Journal of Agricultural and Food Chemistry 55: 7427-7423.
Zeraik, M.L., Pereira, C.A.M., Zuin, V. G., Yariwake. 2010. Maracujá: um alimento funcionale Revista Brasileira de Farmacognosia 20: 459-471. 